\title{
Ultrastructural characteristics and histological impacts of Myxobolus naffari (Myxozoa: Myxosporea) infecting Nile labeo Labeo niloticus (Osteichthyes: Cichlidae)
}

\author{
A. S. Abdel-Baki ${ }^{1,2, *}$, T. Sakran ${ }^{2}$, H. Fayed ${ }^{3}$, E. Zayed ${ }^{2}$ \\ ${ }^{1}$ Zoology Department, College of Science, King Saud University, PO Box 12455, Riyadh 11451, Saudi Arabia \\ ${ }^{2}$ Zoology Department, Faculty of Science, Beni-Suef University, Beni-Suef, Egypt \\ ${ }^{3}$ Zoology Department, Faculty of Science, Cairo University, Giza, Egypt
}

\begin{abstract}
We describe the ultrastructural characteristics and histological impacts of Myxobolus naffari Abdel-Ghaffar et al., 1998, which infects the Nile fish Labeo niloticus. The prevalence of infection was $65 \%$, with the maximum rate occurring during winter and a lower rate during summer. The histological impacts were manifested as a fusion of the gill epithelia, hyperplasia at the ends of the plasmodia, and atrophy of the external surface of the plasmodia. The ultrastructural study revealed that the plasmodial wall was composed of a single unit membrane and bound externally by a thick layer of collagen fibers. The earliest recognizable stage was the disporous pansporoblast. The development of the parasite was asynchronous, with mature and immature spores randomly distributed throughout the plasmodium.
\end{abstract}

KEY WORDS: Myxobolus naffari $\cdot$ Labeo niloticus $\cdot$ Ultrastructure $\cdot$ River Nile $\cdot$ Histology Resale or republication not permitted without written consent of the publisher

\section{INTRODUCTION}

Myxosporea comprises $>2180$ species assigned to 62 genera commonly found in fish (Lom \& Dyková 2006). Myxobolus is the most common and largest myxosporean genus parasitizing fish. Eiras et al. (2005) provided a synopsis of the relevant morphometric and morphological data of 744 nominal species of Myxobolus including nearly all the species described so far in fish and amphibians. Only 14 Myxobolus spp. have been described from fishes caught in Egyptian waters to date (Fahmy et al. 1971, 1975, Abdel-Ghaffar et al. 1995, 1998, 2008, Negm-Eldim et al. 1999, Ali et al. $2002,2003,2007)$. The majority of these species were described using light microscopy and diagrammatic drawings of spores to define species. Only 2 Egyptian Myxobolus spp. have been described using electron microscopy (Ali et al. 2003, 2007). Therefore, the present study was undertaken to study the ultrastructural details of M. naffari that infects the Nile labeo Labeo niloticus. The histological impact of the parasite on the host was also described.

\section{MATERIALS AND METHODS}

During a survey of myxosporean infections of fish species from the River Nile in Egypt, a total of 200 freshly caught Labeo niloticus were examined from March 2008 to March 2009. The examined fish ranged from 23 to $30 \mathrm{~cm}$ in total length. Descriptions and measurements of spores followed the guidelines of Lom \& Arthur (1989). Measurements were based on 30 spores, and data were presented as mean $\pm \mathrm{SD}$ (range). For histology, the infected parts were fixed in $10 \%$ phosphate-buffered formalin, embedded in paraffin, sectioned, and stained with hematoxylin and eosin (H\&E). For electron microscopy, small intact cysts with 
minimal surrounding tissue were isolated and fixed in $3 \%$ glutaraldehyde in $0.1 \%$ sodium cacodylate ( $\mathrm{pH} 7.4$ ), washed in the same buffer, and post-fixed with $2 \% \mathrm{OsO}_{4}$ in the same buffer. The tissue pieces were dehydrated in graded ethanol and embedded in araldite. Ultrathin sections were stained with uranyle acetate and lead citrate and examined with a Philips (208) electron microscope at 80 to $100 \mathrm{kV}$.

\section{RESULTS}

The prevalence of infection was $65 \%$ (130/200), with the maximum rate occurring during winter and the minimum rate in summer.

\section{Light microscopy}

Plasmodia. Plasmodia appeared as white aggregates of tiny rods on the gill filament. Fish were infected with 2 to 16 cysts, the average dimensions of which were $0.6 \pm 0.4$ (range: 0.3 to 1.26 ) $\mathrm{mm}$ in length and $0.2 \pm$ 0.07 (range: 0.1 to 0.2 ) $\mathrm{mm}$ in width.

Spores. Spores were subspherical to ellipsoidal in the frontal view with rounded anterior and posterior ends (Fig. 1). They measured $10.9 \pm 0.4$ (range: 10.5 to 12.0) $\mu \mathrm{m}$ in length and $8.6 \pm 0.5$ (range: 7 to 9.5 ) $\mu \mathrm{m}$ in width (Fig. 1). A small intercapsular process was present. Spore valves were thin, smooth, and symmetrical. Polar capsules were oval, equal in size, and occupied nearly half of the spore length. They measured $5.7 \pm$ 0.2 (range: 5.2 to 6.3 ) $\mu \mathrm{m}$ in length and $3.3 \pm 0.4$ (range: 2.6 to 4.0$) \mu \mathrm{m}$ in width. Polar filaments showed 6 to 8 coils slightly oblique along the axis of the polar capsule. The sporoplasm was binucleated, with a large and rounded to oval iodinophilous vacuole, measuring $3.6 \pm 0.4$ (range: 2.3 to 4.0 ) $\mu \mathrm{m}$ in diameter.

Histological impact. Plasmodia were located inside the lining epithelium covering the gill filaments. The plasmodial mass occupied a large part of the gill filament (Fig. 2). The host reaction was detected as the formation of a thin fibrous connective tissue capsule around the plasmodia (Fig. 2). The histological impacts were manifested as a fusion of the gill epithelia, hyperplasia at the ends of the plasmodia, and atrophy of the external surface of the plasmodia (Fig. 2).

\section{Electron microscopy}

Plasmodia. The plasmodia were surrounded by single unit membranes (Fig. 3). External to the membrane, there was a thick layer composed of collagen fibers in contact with the host cell (Fig. 3). The plas- modium was composed of 2 distinct layers, the outer ectoplasm and an inner endoplasm. The ectoplasm was an amorphous layer with many pinocytotic vesicles, whereas the endoplasm contained the different developmental stages (Fig. 3).

Sporogenesis. The early sporogenic stages were not observed. The earliest recognizable stages were the monosporous and the disporous pansporoblast (Figs. 4 $\& 5)$. As the spore matured, there was a structural progression in the capsulogenesis, sporoplasm maturation, and valvogenesis (Figs. 4 to 9).

Capsulogenesis. Capsulogenic cells occurred at the apical pole of the developing spore. Together with the sporoplasm they formed the central core of spore that was ensheathed by valvogenic cells (Figs. 4, $7 \& 9$ ). The differentiation of the capsulogenic cell started with the appearance of a club-shaped structure, which was the initial stage of the capsular primordium (Fig. 5). Gradually, the initial stage differentiated into the bulbous primordium and the associated external tube (Figs. $5 \&$ $6)$. The external tube was later internalized into the primordium to make the polar filament coils with 6 to 8 turns (Figs. 6, $7 \&$ 9).

The developing polar capsule had a homogeneous core of medium electron density, surrounded by an electron-lucent layer and an outer layer of medium density (Fig. 6). A stopper with a triangular cap-like cover plugged the apex of each mature polar capsule (Fig. 6). Maturation of the 2 polar capsules was usually synchronous (Figs. 7 \& 9)

Sporoplasm. As the polar capsule primordium appeared, the sporoplasm could be easily recognized. In the mature spore, it filled nearly all the space beneath the polar capsules (Figs. 4, $7 \&$ 9). The sporoplasm contained 2 nuclei (Fig. 4) and exhibited dense matrices of sporoplasmosomes (Figs. 4, 7 \& 9). A small area of sporoplasm in mature spores was occupied by glycogen granules that were often vacuolated (Figs. 7 \& 9).

Valvogenesis. Valvogenesis was initiated by the gradual envelopment of the capsulogenic cells and sporoplasm by valvogenic cells. Their nuclei were flattened and located laterally (Fig. 8). In the course of development, these cells gave rise to the 2 shell valves surrounding each spore and the sutural ridge joining the valves (Figs. $7 \&$ 8). At the spore apex, the wall of the valve formed a triangular thickening (Fig. 7).

\section{DISCUSSION}

\section{Light microscopy}

Many species of Myxobolus fall within the morphological and dimensional ranges of the present species. 


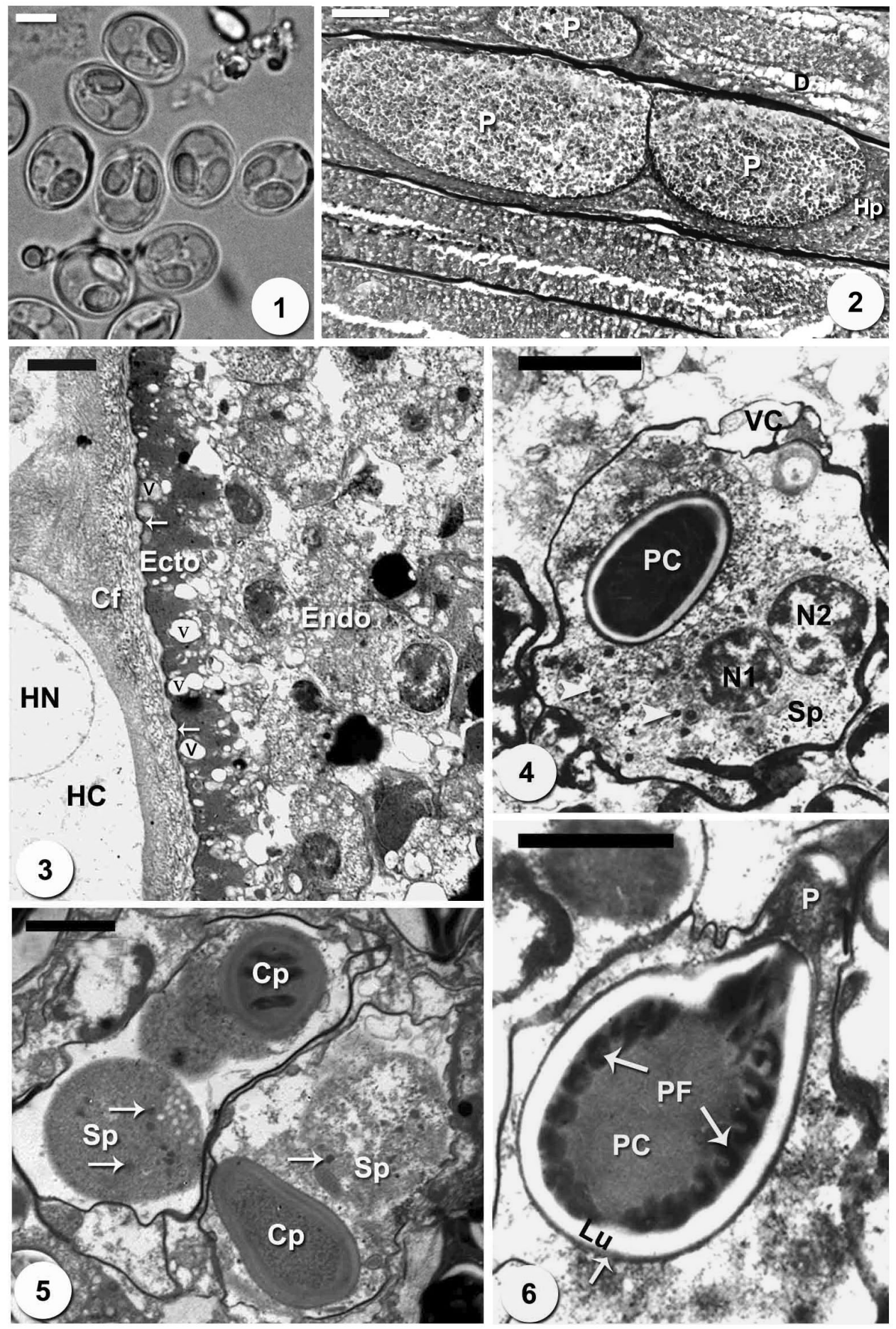

Figs. 1 to 6. Fig. 1. Fresh spores of Myxobolus naffari Abdel-Ghaffar et al., 1998. Scale bar $=5 \mu$ m. Fig. 2. Longitudinal section in infected gill filaments showing many plasmodia (P) with hyperplasia in the gill filament epithelia (Hp) and degeneration (D) along the external surface of the plasmodium. H\&E. Scale bar $=0.2 \mathrm{~mm}$. Fig. 3. Electronmicrograph through a part of $M$. naffari plasmodium showing the plasmodial wall with a single unit membrane (arrows) from which vesicles (v) originated. The plasmodial wall is composed of ectoplasm (Ecto) and endoplasm (Endo). Externally, the plasmodium was surrounded by a layer of collagen fiber (Cf) in contact with the host cell (HC) and host nucleus (HN). Scale bar $=2 \mu \mathrm{m}$. Fig. 4 . Trans-section through mature spore containing 1 mature polar capsule (PC), sporoplasm (Sp) with 2 nuclei (N1, N2), and sporoplasmosomes (white arrowheads) and surrounded by valvogenic cells (VC). Scale bar $=1 \mu \mathrm{m}$. Fig. 5. Trans-section through disporic pansporoblast consisting of 2 asynchronous spore-producing units, each containing capsular primordium (Cp). Sporoplasm (Sp) with sporoplasmosomes (arrows). Scale bar $=1 \mu \mathrm{m}$. Fig. 6. Trans-section through mature polar capsule (PC). The polar capsule is composed of an electrondense outer layer (small arrow), an inner translucent (Lu), and a central dense core. The polar capsules contain polar filament (PF) and have a triangular plug $(\mathrm{P})$ at the apex. Scale bar $=500 \mathrm{~nm}$ 

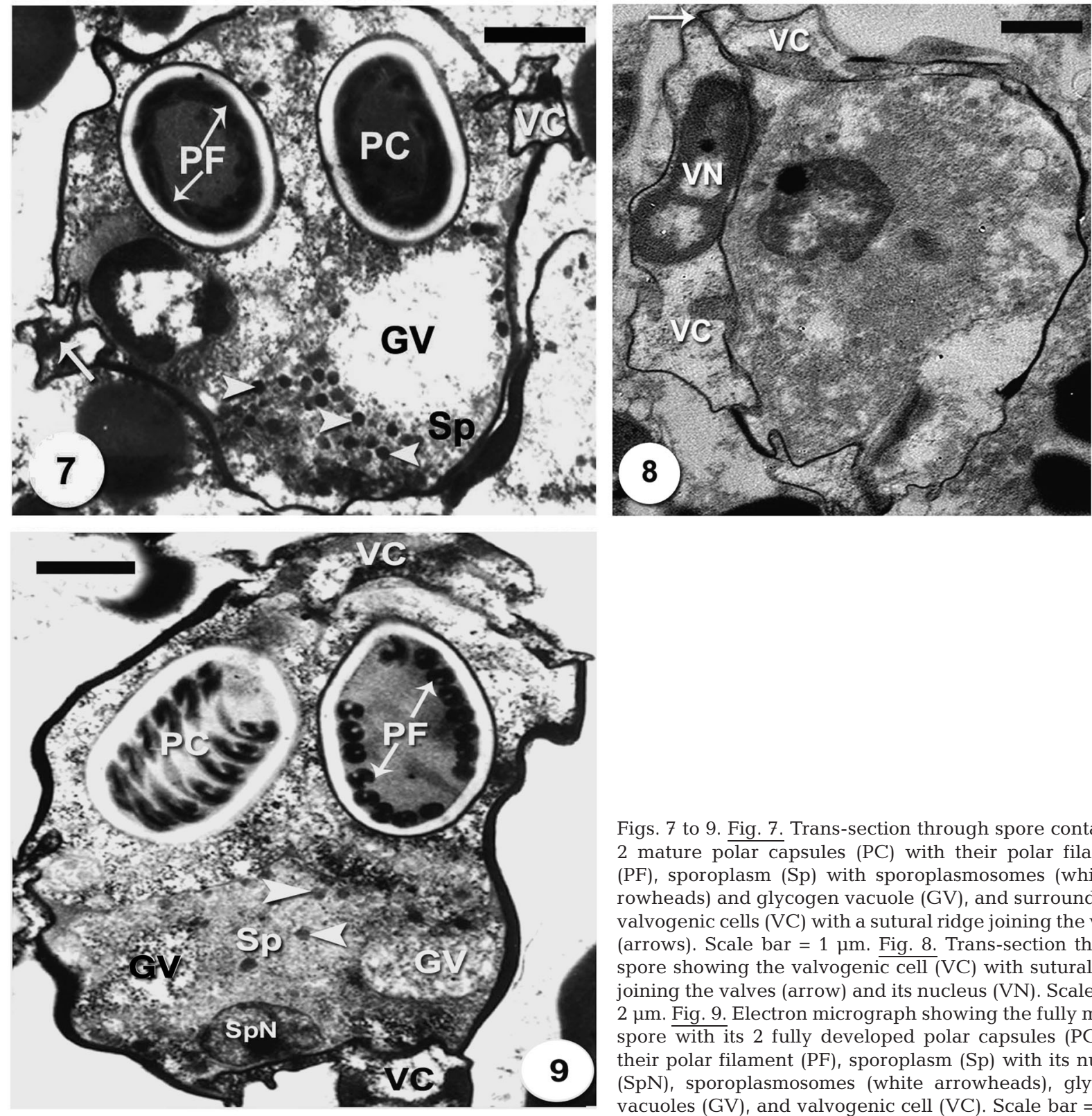

Figs. 7 to 9. Fig. 7. Trans-section through spore containing 2 mature polar capsules (PC) with their polar filaments $(\mathrm{PF})$, sporoplasm (Sp) with sporoplasmosomes (white arrowheads) and glycogen vacuole (GV), and surrounded by valvogenic cells (VC) with a sutural ridge joining the valves (arrows). Scale bar $=1 \mu \mathrm{m}$. Fig. 8. Trans-section through spore showing the valvogenic cell (VC) with sutural ridge joining the valves (arrow) and its nucleus (VN). Scale bar = $2 \mu \mathrm{m}$. Fig. 9. Electron micrograph showing the fully mature spore with its 2 fully developed polar capsules (PC) and their polar filament (PF), sporoplasm (Sp) with its nucleus $(\mathrm{SpN})$, sporoplasmosomes (white arrowheads), glycogen vacuoles $(\mathrm{GV})$, and valvogenic cell (VC). Scale bar $=1 \mu \mathrm{m}$

These include $M$. muelleri Bütschli, 1882 (cited in Lom \& Dyková 1992); M. aldrichetti Su \& White, 1994 from the gills of Aldrichetta forsteri in Australia; M. cognati Cone et al., 1996 from the operculum of Cottus cognatus in Canada; M. mesopotamiae Molnár et al., 1996 from the connective tissue of fins of Barbus grypus in Iran; M. bulbocordis Masoumian et al., 1996 from the heart region of $B$. sharpeyi in Iran; and $M$. naffari Abdel-Ghaffar et al., 1998 and M. imami Ali et al., 2002, both from the gills of Labeo niloticus in Egypt.

Comparatively, Myxobolus muelleri and M. bulbocordis are larger than $M$. naffari in all dimensions, while $M$. aldrichetti and $M$. cognati have pyriform polar capsules and lack an intercapsular process, and $M$. mesopotamiae is smaller in all dimensions and lacks an intercapsular process. M. imami differs from the present species in the number of polar filament turns ( 9 vs. 7 ) and the absence of an intercapsular process. The present species matches $M$. naffari in all morphometric aspects, host, and site of infection. Therefore, the present species can be identified as $M$. naffari.

\section{Histological impact}

In the present study, one host reaction to myxosporean infections is encapsulation of the plasmodia by the gill's connective tissue (Mitchell 1977). The shape, 
site, and histology of Myxobolus naffari match the infection of Henneguya creplini (Haaparanta et al. 1994). Also, the infection led to lamellar fusion, hyperplasia, lamellar atrophy, and inflammation of cells around the plasmodia and destruction of a large proportion of the respiratory epithelia that may render the gills largely nonfunctional due to loss of vital lamellae by the sheer force of the parasite mass (El-Matbouli et al. 1992).

\section{Electron microscopy}

Plasmodia

The plasmodial wall of the present species consisted of a single unit membrane, which is similar to that of some myxoporean species, such as Myxosoma funduli (Current et al. 1979), Myxobolus exiguus (Pulsford \& Matthews 1982), Kudoa lunata (Lom \& Dyková 1988), and Sphaerospora epinepheli (Supamattaya et al. 1993). However, the plasmodia of other myxosporean species may exhibit a double unit membrane as in Henneguya exilis (Current \& Janovy 1977) and Myxobolus sp. (Desser \& Paterson 1978). The differences in the nature of the plasmodium wall are thought to be tissue-dependent (Current \& Janovy 1977).

Externally, the plasmodia were surrounded by a thick layer of collagen fibers similar to that of Henneguya adiposa (Current et al. 1979), Myxobolus exiguus Thelohan, 1895 (Pulsford \& Matthews 1982), Thelohanellus nikolskii Akhmerov, 1955 (Desser et al. 1983), and Zschokkella helmii (Ali et al. 2003).

\section{Sporogenesis}

The sporogenesis of Myxobolus naffari was similar to other described species. The sporogenesis in the present study showed that the spore developed from a 10-cell pansporoblast (disporic pansporoblast). Each spore develops from 5 cells: 2 capsulogenic cells, 2 valvogenic cells, and a binucleated sporoplasmic cell. Similar studies found a 10-cell pansporoblast in Myxobolus spp. plasmodia (Pulsford \& Matthews 1982, Lom et al. 1989, El-Matbouli et al. 1990). This might be due to the full maturation of the present plasmodia, which could explain the lack of the early stages.

\section{Capsulogenesis}

Capsulogenesis of the present species followed the pattern observed in most myxosporeans. According to the literature, the endoplasmic reticulum seems to be the most likely organelle to form the polar capsules. Maturation of the polar capsule of the present species was synchronous. Similar findings were obtained by El-Matbouli et al. (1990) and Casal et al. (1996). After the polar capsule was fully developed, it was plugged with a stopper. A similar structure was reported in the genus Myxobolus by El-Matbouli et al. (1990) and in other myxosporean genera such as Sphaerospora (Lom et al. 1985) and Kudoa (Lom \& Dyková 1988).

\section{Sporoplasm}

In the present species, the sporoplasm was composed of a single binucleated cell, which is in agreement with the findings of El-Matbouli et al. (1990), Casal et al. (1996), and Canning et al. (1999). However, in other myxosporeans, it was found that the sporoplasm was composed of 2 separated cells, e.g. in Sphaerospora renicola (Lom et al. 1983), S. gobioni (Lom et al. 1985), and S. epinepheli (Supamattaya et al. 1993). Stehr (1986) detected a third pattern of the sporoplasm composed of a smaller cell with electron-dense cytoplasm surrounded by a large cell in Kudoa paniformis. Another unique sporoplasmic pattern was reported, in which 4 to 12 sporoplasms were observed in the spore of Polysporoplasm sparis and P. mugilis (SitjàBobadilla \& Alvarez-Pellitero 1995).

The plasmosomes observed in the present material were generally as reported in other studies (Pulsford \& Matthews 1982, El-Matbouli et al. 1990). In contrast, plasmosomes were missing in some myxosporeans, e.g. Sphaerospora epinepheli (Supamattaya et al. 1993) and Myxidium trachinorum (Canning et al. 1999).

The presence of glycogen bodies in the sporoplasm is essential in the myxosporean spore for energy supply for further developmental stages in the spore's life cycle. The present sporoplasm showed small-sized glycogen vacuoles which were similar to those reported in Myxobolus hendricksoni (Mitchell et al. 1985) and $M$. cotti (El-Matbouli et al. 1990).

\section{Valvogenesis}

The spores of Bivalvulida are essentially composed of 2 shell valves. The present valvogenesis includes the typical flat valve cell with its flat nucleus. In the present material the shell valves lack the microtubules, which conforms with observations by Stehr (1986), Lom et al. (1989) and Canning et al. (1999) in the myxosporean species Kudoa paniformis, Myxobolus jiroveci and Myxidium trachinorum, respectively. 
Acknowledgements. We are grateful for the support of the Center of Excellence for Biodiversity Research, College of Science, King Saud University, Riyadh, Saudi Arabia.

\section{LITERATURE CITED}

Abdel-Ghaffar F, El-Shahawi G, Naas S (1995) Myxosporidia infecting some Nile fishes in Egypt. Parasitol Res 81: 163-166

Abdel-Ghaffar F, Ibrahiem EA, Bashter A, Ali MA (1998) Myxosporidia infecting saline and freshwater fishes of Qarun and Wadi El-Raiyan lakes, Egypt (I. Genus: Myxobolus). J Egypt Ger Soc Zool 26(D):209-229

Abdel-Ghaffar F, El-Toukhy A, Al-Quraishy S, Al-Rasheid K, Abdel-Baki AS, Hegazy A, Bashtar AR (2008) Five new myxosporean species (Myxozoa: Myxosporea) infecting the Nile tilapia Oreochromis niloticus in Bahr Shebin, Nile Tributary, Nile Delta, Egypt. Parasitol Res 103:1197-1205

Ali MA, Al-Rasheid AS, Sakran T, Abdel-Baki AS, AbdelGhaffar F (2002) Some species of the genus Myxobolus (Myxozoa: Myxosporea) infecting freshwater fishes of the River Nile, Egypt. Parasitol Res 88:9-15

Ali MA, Abdel-Baki AS, Sakran T, Entzeroth R, AbdelGhaffar F (2003) Light and electron microscopic studies of Myxobolus stomum n. sp. (Myxosporea: Myxobolidae) infecting the blackspotted grunt Plectorhynicus gaterinus (Forsskal, 1775) in the Red Sea, Egypt. Parasitol Res 91: 390-397

Ali MA, Abdel-Baki AS, Sakran Th, Entzeroth R, Abdel-Ghaffar F (2007) Myxobolus lubati n. sp. (Myxosporea: Myxobolidae), a new parasite of haffara seabream Rhabdosargus haffara (Forsskal, 1775), Red Sea, Egypt: a light and transmission electron microscopy. Parasitol Res 100: 819-827

Canning EU, Curry A, Anderson CL, Okamura B (1999) Ultrastructure of Myxidium trachinorum sp. nov. from the gallbladder of the lesser weever fish Echiichthys vipera. Parasitol Res 85:910-919

Casal C, Matos E, Azevedo C (1996) Ultrastructure data on the life cycle stages of Myxobolus braziliensis n. sp., parasite of an Amazonian fish. Eur J Prositol 32:123-127

Cone DK, Stickel RG, Eck GE, Muzzall PM (1996) Myxobolus cognati n.sp. (Myxosporea) from the opercular integument of Cottus cognatus (Cottidae) in Lake Michigan. J Parasitol 82:137-139

Current WL, Janovy J Jr, Knight SA (1979) Myxosoma funduli Kudo (Myxosporidia) in Fundulus kansae: ultrastructure of the plasmodium wall and of sporogenesis. J Protozool 26:574-583

Current WL, Janovy J Jr (1977) Sporogenesis in Henneguya exilis infecting the channel catfish: an ultrastructural study. Protistologica 13:157-167

> Desser SS, Paterson WB (1978) Ultrastructural and cytochemical observation on sporogenesis of Myxobolus sp. (Myxosporidia: Myxobolidae) from common shiner Notropis cornutus. J Protozool 25:314-326

Desser SS, Molnár K, Weller I (1983) Ultrastructure of sporogenesis of Thelohanellus nikolskii Akhmerov, 1955 (Myxozoa: Myxosporea) from the common carp Cyprinus carpio. J Parasitol 69:504-518

Eiras JC, Molnár K, Lu YS (2005) Synopsis of the species of Myxobolus Bütschli, 1882 (Myxozoa: Myxosporea: Myxobolidae). Syst Parasitol 61:1-46

El-Matbouli M, Fischer-Scherl T, Hoffmann RW (1990) Light and electron microscopic studies on Myxobolus cotti ElMatbouli and Hoffmann, 1987 infecting the central ner- vous system of the bullhead (Cottus gobio). Parasitol Res 76:219-227

El-Matbouli M, Fischer-Scherl T, Hoffman RW (1992) Present knowledge on the life cycle, taxonomy, pathology and the therapy of some Myхоsporea spp. important for freshwater fish. Annu Rev Fish Dis 2:367-402

Fahmy MA, Mandour AM, El-Naffar MK (1971) Myxobolus niloticus $\mathrm{n}$. $\mathrm{sp}$. in the fish Labeo niloticus from the River Nile of Assiut. J Egypt Soc Parasitol 1:39-46

Fahmy MA, Mandour AM, El-Naffar MK (1975) A survey of Myxosporidia of the freshwater fishes collected from the River Nile at Assiut province. J Egypt Soc Parasitol 5: 93-102

> Haaparanta AE, Valtonen T, Hoffmann RW (1994) Pathogenicity and seasonal occurrence of Henneguya creplini (Protozoa, Myxosporea) on the gills of perch Perca fluviatilis in central Finland. Dis Aquat Org 20:15-22

> Lom J, Arthur JR (1989) A guideline for the preparation of species descriptions in Myxosporea. J Fish Dis 12:151-156

> Lom J, Dyková I (1988) Sporogenesis and spore structure in Kudoa lunata (Myxosporea, Multivalvulida). Parasitol Res 74:521-530

Lom J, Dyková I (1992) Protozoan parasites of fishes. Elsevier Science, Amsterdam

> Lom J, Dyková I (2006) Myxozoan genera: definition and notes on taxonomy, life cycle terminology and pathogenic species. Folia Parasitol (Praha) 53:1-36

Lom J, Dyková I, Lhotaková S (1983) Fine structure of Sphaerospora renicola Dykova and Lom, 1982, a myxospoean from carp kidney, and comments on the origin of pansporoblast. Protistologica 18:489-502

> Lom J, Pavlaskova M, Dyková I (1985) Notes on kidney infecting species of the genus Sphaerospora Thélohan (Myxosporea), including a new species $S$. gobionis sp. nov., and on myxosporean life cycle stages in blood of some freshwater fish. J Fish Dis 8:221-232

Lom J, Feist S, Dyková I, Kepr T (1989) Brain myxoboliasis of bullhead, Cottus gobio L., due to Myxobolus jiroveci sp. nov.: light and electron microscope observations. J Fish Dis 12:15-27

> Masoumian A, Baska F, Molnár K (1996) Description of Myxobolus bulbocordis (Myxosporea: Myxobolidae) from the heart of Barbus sharpey (Gunther) and histopathological changes produced by the parasite. J Fish Dis 19:15-21

Mitchell LG (1977) Myxosporidia. In: Kreier JF (ed) Parasitic protozoa, Vol 4. Academic Press, New York, NY, p 115-154

Mitchell LG, Seymour CL, Gamble JM (1985) Light and electron microscopy of Myxobolus hendricksoni sp. nov. (Myxozoa: Myxobolidae) infecting the brain of the fathead minnow, Pimephales promelas Rafinesque. J Fish Dis 8: 75-89

Molnár K, Masoumian M, Abasi S (1996) Four new Myxobolus spp. (Myxosporea: Myxobolidae) from Iranian barboid fishes. Arch Protistenkd 147:115-123

Negm-Eldim NM, Govedich FR, Davies RW (1999) Gill myxosporeans on some Egyptian freshwater fish. Dtsch Tierarztl Wochenschr 106:459-465

Pulsford A, Matthews RA (1982) An ultrastructure study of Mxyobolus exiguus Thelohan, 1895 (Myxosporea) from grey mullet, Crenimugil labrosus (Risso). J Fish Dis 5: 509-526

Sitjà-Bobadilla A, Alvarez-Pellitero P (1995) Light and electron microscopic description of Polysporoplasma n. $\mathrm{g}$. (Myxosporea: Bivalvulida), Polysporoplasma sparis n. sp. from Sparus aurata (L.), and Polysporoplasma mugilis from Liza aurata L. Eur J Protistol 31:77-89 
Stehr C (1986) Sporogenesis of the myxosporean Kudoa paniformis Kabata and Whitaker, 1981 infecting the muscles of the Pacific whiting, Merlucius productus (Ayres). J Fish Dis 9:493-504

Su X, White RWG (1994) New myxosporeans (Myxozoa: Myxosporea) from marine fishes of Tasmania, Australia.

Editorial responsibility: Dieter Steinhagen,

Hannover, Germany
Acta Protozool 33:251-259

Supamattaya K, Fischer-Scherl T, Hoffmann RW, Boonyaratpalin S (1993) Light and electron microscopic observations on presporogenic and sporogenic stages of Sphaerospora epinepheli (Myxosporea) in grouper (Epinephellus malabaricus). J Eukaryot Microbiol 40:71-80

Submitted: April 8, 2010; Accepted: May 6, 2010

Proofs received from author(s): June 21, 2010 